\title{
Katastrofiziranje u bolesnika sa sindromom pekućih usta
}

\section{Catastrophizing in Patients with Burning Mouth Syndrome}

Zavod za oralnu medicinu Stomatološkog fakulteta Sveučilišta u Zagrebu, Hrvatska
Department of Oral Medicine, School of Dental Medicine, University of Zagreb, Croatia

\section{Sažetak}

Uvod: Sindrom pekućih usta (SPU) idiopatska je tegoba kod koje usna šupljina peče i boli pacijente s klinički normalnom oralnom sluznicom. Pritom su isključeni lokalni i opći uzroci. Katastrofiziranje se definira kao pretjerana negativna orijentacija prema osjećaju boli i bolnog iskustva. Svrha ovog rada bila je ispitati povezanost između katastrofiziranja i kliničkih parametara SPU-a te između katastrofiziranja i kvalitete života bolesnika s SPU-om. Materijali i metode: Anonimni trodijelni upitnik [opći parametri i vizualna analogna ljestvica (VAS) za procjenu intenziteta pečenja (od 0 do 100 mm), hrvatska inačica OHIP-ove ljestvice (OHIP 14) te hrvatska verzija ljestvice Pain Catastrophizing] ispunilo je 30 pacijenata s dijagnosticiranim SPU-om. Rezultati: Katastrofiziranje je bilo klinički značajno izraženo kod 30 posto bolesnika. Ukupno katastrofiziranje i sve tri potkomponente bile su u korelaciji s intenzitetom pečenja, ali ne i s trajanjem tegoba. Pacijenti sa snažnijim katastrofiziranjem imali su lošiju kvalitetu života. Spol nije utjecao na to stanje. Zaključak: Uvidom u katastrofiziranje moglo bi se identificirati pacijente s negativnim obrascima ponašanja kod kojih bi se dodatnom psihološkom intervencijom mogli smanjiti ili eliminirati negativni kognitivni čimbenici i poboljšati podnošenje kroničnoga bolnog stanja kao što je SPU.
Zaprimljen: 3. ožujka 2014 Prihvaćen: 7. svibnja 2014.

Adresa za dopisivanje

Doc.dr.sc. Vlaho Brailo

Sveučilište u Zagrebu

Stomatološki fakultet

Zavod za oralnu medicinu

Gundulićeva 5, 10000 Zagreb, Hrvatska

brailo@sfzg.hr

Ključne riječi

sindrom pečenja usta; katastrofičan stav; kvaliteta života; psihološka prilagodba

\section{Uvod}

Sindrom pekućih usta (SPU) idiopatska je tegoba za koju su svojstveni pečenje i bol u usnoj šupljini kod pacijenata s klinički normalnom oralnom sluznicom. Pritom su isključeni lokalni ili sistemski uzroci (1). Deset do petnaest posto žena $u$ postmenopauzi $u$ anamnezi navodi pečenje $u$ usnoj šupljini, a simptomi su najčešći od tri do dvanaest godina nakon menopauze (2). Prevalencija pacijenata s pečenjem $\mathrm{u}$ ustima nepoznate etiologije iznosi od 0,7 do 7,9 posto opće populacije (3). Etiologija SPU-a i dalje je nepoznata, iako su predloženi čimbenici klasificirani kao lokalni (suhoća usta, parafunkcijske navike, oralni galvanizam), sistemski (dijabetes, nutricijski deficiti - nedostatak serumskog željeza, vitamina B1, B2, B6, B12 i folne kiseline), psihogeni i idiopatski $(1,3)$. Slijedom toga, Scala i suradnici preporučuju osnovnu distinkciju između primarnoga SPU-a (pravi, idiopatski kojemu se ne može identificirati ni lokalni ni sistemski uzrok) i sekundarnoga (uzrokovan lokalnim ili sistemskim poremećajem koji se može etiološki liječiti) (1). Više od 60 posto bolesnika istaknulo je poremećaj okusne osjetljivosti (disgeuzija), a većina navodi gorčinu u ustima, pa se pretpostavlja da bi SPU mogao biti posljedica oštećenja perifernih osjetilnih neuralnih mehanizama (2). SPU se povezuje i sa psihičkim poremećajima, najčešće depresijom, no nije jasno je li ona uzrok ili posljedica kroničnoga bolnog stanja poput SPU-a (2). Simptomi pečenja lokalizirani su simetrično (bilateralno) i vrlo su često izolirani na prednjoj trećini jezika, usnicama, nepcu i ždrijelu, a može biti zahvaćena i sluznica ci-

\section{Introduction}

Burning mouth syndrome (BMS) is an idiopathic painful condition manifested with burning sensations in the oral cavity in people with clinically normal oral mucosa and no identifiable local and/or systemic cause (1). Ten to fifteen percent of postmenopausal women have a history of burning in their mouth and these symptoms are most commonly reported 3-12 years after menopause (2). The prevalence of patients with BMS in general population is reported to be $0.7 \%-7.9 \%$ (3). The underlying aetiology is still unknown, although the proposed underlying factors are classified as local (xerostomia, candidal infection), systemic (diabetic neuropathy, nutritional deficiencies - lack of serum iron, vitamin B1, B2, B6, B12 and folic acid), psychogenic and idiopathic $(1,3)$. Scala et al. (4) recommended a basic distinction between 'primary BMS' (true, idiopathic in which local or systemic cause cannot be identified), and 'secondary BMS' (caused by local or systemic disorder that can be treated) (1). In more than $60 \%$ of patients altered taste sensitivity (dysgeusia) is reported which indicates the possibility of damaged peripheral sensory neural mechanisms (2). BMS is also associated with psychological disorders, most commonly depression, but it remains unclear whether depression is a cause or consequence of chronic pain condition such as BMS (2). Burning symptoms are localized symmetrically (bilaterally), often isolated in the front third of the tongue, the lips, the palate, the pharynx, but the entire oral mucosa may be affected. Symptoms are spontaneous and present through- 
jele usne šupljine. Spontani su i svakodnevni, slabiji ujutro, uz tipično pogoršavanje prema večeri, ali bolesnika noću ne bude (1). Simptome pečenja znatno olakšava konzumiranje hrane i pića, slastica i guma za žvakanje. Bolesnici su često jako zabrinuti zbog svojega stanja i ističu da su općenito uznemireni ili napeti (2). Kancerofobija je vrlo česta i pojavljuje se kod njih od 45 do 75 posto (5). Dijagnoza SPU-a postavlja se na temelju eliminacije lokalnih i sistemskih stanja koja mogu biti praćena simptomima pečenja klinički zdrave oralne sluznice (4). S obzirom na to da je etiologija SPU-a nepoznata, još ne postoji jedinstveni lijek za ovo bolno stanje (1). Budući da su psihogeni čimbenici čvrsto vezani uz SPU, često se koristi psihološka terapija - samostalno ili u kombinaciji s drugim tretmanima. Među psihološkim pristupima učinkovitost je dokazana jedino za kognitivno-bihevioralnu terapiju, s naglaskom na smanjenje utjecaja disfunkcijskoga kognitivnog čimbenika (katastrofiziranje, anksioznost i sl.) (3). Mogu se izabrati i potporne terapijske mogućnosti poput topikalno primijenjenog kapsaicina, niskih doza peroralno primijenjenog klonazepama, niskih doza tricikličkih antidepresiva te alfa lipoične kiseline. No ni jedan od navedenih medikamenata u kontroliranim se studijama nije pokazao učinkovitim (1). Katastrofiziranje se definira kao pretjerana negativna orijentacija prema osjećaju boli i bolnom iskustvu (6). Sastoji se od triju potkomponenti - promišljanja (primjerice: Neprestano mislim na bol $i$ želim da prestane), preuveličavanja (primjerice: Pitam se bi li mi se moglo dogoditi nešto ozbiljno) i bespomoćnosti (primjerice: Užasno mi je i mislim da nikada više neće biti bolje). Važan je prediktor intenziteta boli i načina na koji pacijenti podnose bol te kako odgovaraju na primijenjenu terapiju $(7,8)$. Ljestvica Pain Catastrophizing psihološki je instrument koji je razvio Sullivan, a objektivizira katastrofiziranje povezano s boli (9).

Svrha ovog rada bila je ispitati razinu katastrofiziranja bolesnika sa SPU-om i vezu između katastrofiziranja i kvalitete života bolesnika.

\section{Ispitanici i postupci}

Istraživanje je odobrilo Etičko povjerenstvo Stomatološkog fakulteta Sveučilišta u Zagrebu. U istraživanju je sudjelovalo 30 ispitanika s dijagnosticiranim primarnim SPU-om. Svi su potpisali informirani pristanak. Kriterij za postavljanje dijagnoze primarnoga SPU-a bilo je pečenje klinički zdrave oralne sluznice najmanje tri mjeseca te odsutnost lokalnih i/ ili sistemskih čimbenika koji mogu uzrokovati te simptome. Lokalni i sistemski čimbenici eliminirali su se određivanjem kvantuma salivacije (10) te nalazima kompletne krvne slike, serumskog željeza, vitamina B12, folne kiseline i glukoze u krvi. Isključni kriteriji bili su nemogućnost razumijevanja svrhe i naravi istraživanja te sadržaja informiranog pristanka i prisutnost lokalnog i/ili sistemskog čimbenika koji može uzrokovati pečenje oralne sluznice.

Nakon postavljanja dijagnoze primarnoga SPU-a, ispitanici su dobili anonimni upitnik, pa nisu upisivali osob- out the day, less pronounced in the morning, with a typical deterioration towards the end of the day, but with no discomfort during the night. Sleep is not affected (1). Burning symptoms subside with drinks and food intake, chewing gums and candies. Patients are often very concerned about their condition and they are generally anxious or upset (2). Cancerophobia is a common feature in BMS and is reported in $45 \%-75 \%$ of the patients (5). The diagnosis of primary BMS is based upon exclusion of local and systemic conditions that may be associated with burning sensations of clinically normal oral mucosa (4).

Because of the unknown aetiology, there is still no proper treatment for BMS (1). Since the psychogenic factors are strongly associated with BMS symptomatology, psychological treatment, with or without other approaches is frequently used. Among these treatments, cognitive behavioural therapy, focusing on reducing the impact of dysfunctional cognitive factors (catastrophizing, anxiety, etc.) is the only psychological approach that has been confirmed as an effective treatment for BMS (3). Supportive therapeutic options such as topical capsaicin, low dose clonazepam, low-dose tricyclic antidepressants, and alpha lipoic acid are also available, but none of them can provide complete resolution of the symptoms (1).

Catastrophizing has been defined as an exaggerated negative orientation toward pain stimuli and pain experience (6). It consists of three sub components - rumination ("I worry all the time whether the pain will end"), magnification ("I wonder whether something serious might happen") and helplessness (It's awful and I feel it overwhelms me"). Catastrophizing affects the modulation of pain stimulus, the way patients cope with their pain, and the response to the treatment $(7,8)$. The Pain catastrophizing (PC) scale is a psychological instrument developed by Sullivan and Bishop which objectifies catastrophizing associated with pain (9).

The aim of this study was to examine the association between catastrophizing and clinical parameters of BMS, and to examine the association between catastrophizing and the quality of life in patients with BMS.

\section{Materials and methods}

The study was approved by the Ethics Committee of the School of Dental Medicine, University of Zagreb. Thirty patients diagnosed with primary BMS participated in the study. Informed consent was obtained from each patient. The criteria for the diagnosis of primary BMS were: burning sensations in clinically normal oral mucosa of min 3 months duration and the absence of any local and/or systemic factor that can lead to burning sensations in the oral cavity. Local and systemic factors were eliminated with the salivary flow rate measurement (10), complete blood count, serum iron, vitamin B12 and folic acid, and blood glucose levels. Exclusion criteria were the inability to understand the text of the informed consent and the presence of an identifiable local and/or systemic factor that could lead to burning sensation in the oral mucosa.

A questionnaire was given to all patients, after the diagnosis of primary BMS was established, but before the condi- 
ne podatke poput imena, prezimena, datuma rođenja, adrese i sl.

Upitnik se sastojao od tri dijela. U prvom dijelu upisivali su se opći parametri (spol, dob, koliko dugo traju simptomi, je li već bilo neuspješnih pokušaja liječenja, postoji li neki drugi idiopatski bolni poremećaj te uzimanje lijekova). Za subjektivnu procjenu utjecaja pečenja na opće stanje, ispitanici su odgovarali zaokruživanjem jednog od triju ponuđenih odgovora: 1 - značajno utječe, 2 - utječe, 3 - ne utječe. Za procjenu jakosti pečenja koristila se vizualno analogna ljestvica ( $0=$ bez pečenja, $100=$ najgore moguće pečenje). Drugi dio upitnika bila je hrvatska verzija upitnika Oral Health Impact Profila (11), a pacijenti su odgovarali na 14 pitanja o kvaliteti života, zaokružujući jedan od ponuđenih odgovora: 0 - nikad, 1 - gotovo nikad, 2 - povremeno, 3 često i 4 - vrlo često. Treći dio upitnika ispitivao je katastrofiziranje boli s pomoću hrvatske verzije ljestvice Pain Catastrophising (PC) (12), a ispitanici su odgovarali na 13 pitanja upisujući jedan od ponuđenih odgovora: 0 - nimalo, $1-\mathrm{u}$ maloj količini, 2 - u umjerenoj količini, 3 - u značajnoj količini i 4 - neprestano. Izvorna PC-ljestvica procjenjuje bol, a ne simptome pečenja te se riječ bol proteže kroz upitnik. Ispitanici su prije ispunjavanja upitnika instruirani da kada pročitaju riječ bol misle na svoje pečenje.

Podatci su organizirani u tablične datoteke (Microsoft Excell, Microsoft Inc. SAD) i statistički obrađeni programom SPSS v20 softver (IBM Inc, SAD). Normalnost distribucije testirana je Kolmogorov-Smirnovljevim testom. Za ispitivanje razlika između ispitanika korišteni su hi-kvadrat test, Welchov t-test i analiza varijance. Korelacija između pojedinih varijabli ispitivala se Pearsonovim koeficijentom korelacije. Vrijednosti p niže od 0,05 $(\mathrm{p}<0,05)$ smatrale su se statistički značajnima.

\section{Rezultati}

U istraživanju je sudjelovalo 30 ispitanika [25 žena (83,3 posto) i 5 muškaraca (16,7 posto)]. Prosječna dob iznosila je $66,1 \pm 9,2$ godine. Ostale demografske i kliničke osobitosti nalaze se u tablici 1 .

Nisu utvrđene statistički značajne razlike u demografskim i kliničkim osobitostima između žena i muškaraca.

Utjecaj pečenja na kvalitetu života prikazan je u tablici 2.

Nisu pronađene statistički značajne razlike između muškaraca i žena u kvaliteti života $(\mathrm{p}=0,385)$. Nisu ustanovljene razlike u kvaliteti života između ispitanika koji su već bili liječeni i onih koji nisu $(\mathrm{p}=0,880)$.

Kod ispitanika koji su izjavili da SPU značajno utječe na njihovo opće stanje, utvrđena je niža kvaliteta života u odnosu na one koji su istaknuli kako SPU utječe na njihovo opće stanje i ispitanika koji su rekli da SPU ne utječe na njihovo opće stanje $(\mathrm{p}=.005)$. tion was explained and discussed with the patient. The questionnaire was completely anonymous and no personal data such as name, surname, date of birth, address, etc. was entered.

The questionnaire consisted of three parts. The first part included demographic and clinical parameters of the participating subjects (gender, age, duration of the symptoms, medications, subjective assessment of BMS impact on general wellbeing and previous treatment for BMS). For the subjective assessment of the BMS, the impact on general wellbeing - a three point scale (1 - significantly affects, 2 - affects, 3 - does not affect) was used. For the assessment of burning intensity, a $100 \mathrm{~mm}$ visual-analogue scale was used $(0=$ no burning, 100= worst burning imagined). The second part of the questionnaire consisted of the Croatian version of the Oral Health Impact Profile Questionnaire 14 (OHIP-14) (11). Patients expressed their level of agreement with 14 questions about the oral health related quality of life, by choosing one of the answers: 0-never, 1-almost never, 2-sometimes, 3 often-and 4-very often. The third part of the questionnaire examined catastrophizing in pain using the Croatian version of the PC scale (12), where subjects expressed frequency of negative thoughts (presented in 13 statements) related to the burning in their mouth with one of the following answers: 0 -not at all, 1-to a slight degree, 2-to a moderate degree, 3 to a great degree, 4-all the time. The original PC scale assesses pain rather than burning sensation and the word "pain" is used throughout the scale. The participants were, therefore instructed to reflect only on burning in their mouth when reading the word "pain".

Data were organized in Excel worksheets (Microsoft Excel, Microsoft Inc. U.S.) and statistically analysed using SPSS v20 software (IBM Inc, USA). Normality of the distribution was tested with the Smirnov Kolmogorov test. Chisquare test, Welch's $t$ test and analysis of variance were used to test intergroup differences when appropriate. Correlation between variables was assessed by Pearson correlation coefficient $(r)$. The $p$ values lower than $0.05(p<0.05)$ were considered statistically significant.

\section{Results}

Thirty patients participated in the study (25 women $83.3 \%$ and 5 men $-16.7 \%)$. The average age of the patient was $66.1 \pm 9.2$ years. Other demographic and clinical characteristics of the patients are shown in Table 1.

No significant differences in demographic and clinical parameters between men and women were found.

Oral health related quality of life and pain catastrophizing are presented in Table 2.

No significant differences between men and women regarding the quality of life were found $(\mathrm{p}=0.385)$. There were no differences in quality of life between patients who were previously treated for BMS and those who were not previously treated for BMS $(\mathrm{p}=0.880)$. Patients who reported that BMS significantly affected their general wellbeing had lower quality of life than patients who reported that BMS affected their wellbeing and patients who reported 
Tablica 1. Demografske i kliničke karakteristike ispitanika

Table 1 Demographic and clinical characteristics of patients

\begin{tabular}{|c|c|c|}
\hline Spol • Gender $(\mathrm{N} ; \%)$ & & p \\
\hline Ženski • Women & $25 ; 83.3 \%$ & \\
\hline Muški • Men & $5 ; 16.7 \%$ & \\
\hline Dob (sr. vrijednost \pm SD) • Age $($ mean \pm SD) & $66.1 \pm 9.2$ & 0.865 \\
\hline \multicolumn{3}{|l|}{ Radni status • Employment status (N;\%) } \\
\hline Umirovljenik/ca $\bullet$ Retired & $24 ; 80 \%$ & \multirow{3}{*}{0.887} \\
\hline Zaposlen/a $\bullet$ Employed & $4 ; 13.3 \%$ & \\
\hline Nezaposlen/a • Unemployed & $2 ; 6.7 \%$ & \\
\hline $\begin{array}{l}\text { Trajanje tegoba }(\text { sr. vrijednost } \pm \text { SD) } \bullet \\
\text { Duration of symptoms months }(\text { mean } \pm \text { SD) }\end{array}$ & $21.9 \pm 21.1$ & 0.112 \\
\hline Intenzitet tegoba VAS (sr. vrijednost \pm SD) $\bullet$ Symptom intensity VAS (mean \pm SD) & $5.8 \pm 2$ & 0.734 \\
\hline \multicolumn{3}{|l|}{ Utjecaj pečenja na opće stanje • Impact of BMS on general wellbeing (N;\%) } \\
\hline Značajno utječe $\bullet$ Significantly affects & $7 ; 23.3 \%$ & \multirow{3}{*}{0.579} \\
\hline Utječe $\bullet$ Affect & $19 ; 63.3 \%$ & \\
\hline Ne utječe $\bullet$ Does not affect & $4 ; 13.3 \%$ & \\
\hline \multicolumn{3}{|l|}{ Prethodno liječenje $\bullet$ Previous treatment of BMS } \\
\hline Nije liječen/a $\bullet$ Not treated & $20 ; 66.7 \%$ & \multirow{4}{*}{0.056} \\
\hline Stomatolog $\bullet$ Dentist & $6 ; 20 \%$ & \\
\hline Liječnik obiteljske medicine $\bullet$ General practitioner & $3 ; 10 \%$ & \\
\hline Specijalist ORL $\bullet$ ENT specialist & $1 ; 3.3 \%$ & \\
\hline \multicolumn{3}{|l|}{ Uspješnost prethodnog liječenja • Success of previous treatment $(\mathrm{N} ; \%)$} \\
\hline Potpuna sanacija $\bullet$ Complete relief & 0 & \\
\hline Djelomično poboljšanje $\bullet$ Partial relief & 0 & \\
\hline Bez uspjeha $\bullet$ No relief & $10 ; 100 \%$ & \\
\hline
\end{tabular}

Tablica 2. Kvaliteta života i katastrofiziranje

Table 2 Oral health related quality of life and pain catastrophizing

\begin{tabular}{|l|c|c|c|}
\hline & $\begin{array}{c}\text { Sr. vrijednost } \pm \text { SD } \\
\text { Mean } \pm \text { SD }\end{array}$ & $\begin{array}{c}\text { Razlike prema spolu } \bullet \\
\text { Gender differences }\end{array}$ & $\begin{array}{c}\text { Utjecaj SPU-a na opće } \\
\text { stanje } \bullet \text { BMS impact on } \\
\text { general wellbeing }\end{array}$ \\
\hline OHIP 14 & $19.1 \pm 10.8$ & 0.410 & $0.005^{*}$ \\
\hline $\begin{array}{l}\text { Prethodna terapija } \bullet \\
\text { Catastrofiziranje (ukupno) }\end{array}$ & $28.4 \pm 15$ & 0.279 & $0.005^{*}$ \\
\hline Razmišljanje $\bullet$ Rumination & $10.2 \pm 5$ & 0.191 & 0.908 \\
\hline Preuveličavanje $\bullet$ Magnification & $6.9 \pm 3.4$ & 0.568 & $0.018^{*}$ \\
\hline Bespomoćnost $\bullet$ Helplessness & $11.2 \pm 7.4$ & 0.298 & 0.499 \\
\hline
\end{tabular}

* statistički značajna razlika $(\mathrm{p}<0,05) \bullet$ statistically significant difference $(\mathrm{p}<0.05)$

Nisu pronađene statistički značajne razlike u ukupnom katastrofiziranju ni u pojedinim njegovim komponentama između žena i muškaraca $(p=0,244)$. Ispitanici koji su izjavili da SPU značajno utječe na njihovo opće stanje, imali su viši iznos ukupnoga katastrofiziranja te u svim trima potkomponentama, za razliku od onih koji su izjavili da SPU utječe i ne utječe na njihovo opće stanje $(\mathrm{p}=0,002)$.

Nisu ustanovljene statistički značajne razlike u ukupnom katastrofiziranju ni u pojedinim komponentama katastrofiziranja između ispitanika koji su već bili liječeni i onih koji nisu bili $(\mathrm{p}=0,913)$.

Odnos između katastrofiziranja, kvalitete života, intenziteta i trajanja simptoma pečenja prikazan je u tablici 3 .

Utvrđena je pozitivna korelacija između ukupnog katastrofiziranja i intenziteta simptoma te rezultata OHIP-ova mjerenja $(r=0,538 ; r=0,694)$. Također je ustanovljena pozitivna korelacija između svih triju komponenata katastrofi- that BMS did not affect their general wellbeing, respectively $(\mathrm{p}=0.005)$.

No significant differences neither in total catastrophizing score nor in the individual subcomponents of catastrophizing between women and men were found $(\mathrm{p}=0.244)$. Patients who reported that BMS significantly affected their general wellbeing had significantly higher scores of total catastrophizing and all three subcomponents of catastrophizing than patients who reported that BMS affected their general wellbeing and patients who reported that BMS did not affect their general wellbeing, respectively $(\mathrm{p}=0.002)$.

No significant differences in total catastrophizing score and individual subcomponents of catastrophizing between patients who were previously treated for BMS and patients who were not previously treated for BMS were found $(\mathrm{p}=0.913)$.

The association between catastrophizing, quality of life, intensity and duration of the symptoms is shown in Table 3. 
ziranja i intenziteta simptoma te kvalitete života. Nije pronađena pozitivna korelacija između katastrofiziranja i trajanja simptoma.
Significant positive correlation was found between total catastrophizing and intensity of the symptoms and the quality of life, $(r=0.538 ; r=0.694)$ respectively. Furthermore, significant positive correlation between all three subcomponents of catastrophizing and intensity of the symptoms and the quality of life was also found, respectively. No significant correlation between catastrophizing and duration of the symptoms was found.

Tablica 3. Odnos između katastrofiziranja, kvalitete života, intenziteta i trajanja simptoma kod pacijenata sa SPU-om

Table 3 The association between catastrophizing, quality of life, intensity and duration of the symptoms in patients with BMS

\begin{tabular}{|c|c|c|c|}
\hline & Intenzitet $\bullet$ Intensity & $\begin{array}{l}\text { Koeficijent korelacije • } \\
\text { Correlation coefficient }\end{array}$ & Značajnost $\bullet$ Significance \\
\hline Katastrofiziranje (ukupno) $\bullet$ Catastrophizing (total) & & 0.538 & $0.002^{*}$ \\
\hline Razmišljanje $\bullet$ Rumination & & 0.491 & $0.006^{*}$ \\
\hline Preuveličavanje $\bullet$ Magnification & & 0.475 & $0.008^{*}$ \\
\hline \multirow[t]{2}{*}{ Bespomoćnost $\bullet$ Helplessness } & & 0.536 & $0.002^{*}$ \\
\hline & Trajanje $\bullet$ Duration & $\begin{array}{l}\text { Koeficijent korelacije } \bullet \\
\text { Correlation coefficient }\end{array}$ & Značajnost $\bullet$ Significance \\
\hline Katastrofiziranje (ukupno) • Catastrophizing (total) & & -0.005 & 0.981 \\
\hline Razmišljanje $\bullet$ Rumination & & 0.32 & 0.867 \\
\hline Preuveličavanje $\bullet$ Magnification & & -0.098 & 0.607 \\
\hline \multirow[t]{2}{*}{ Bespomoćnost $\bullet$ Helplessness } & & 0.014 & 0.940 \\
\hline & OHIP-14 & $\begin{array}{l}\text { Koeficijent korelacije • } \\
\text { Correlation coefficient }\end{array}$ & Značajnost $\bullet$ Significance \\
\hline Katastrofiziranje (ukupno) • Catastrophizing (total) & & 0.694 & $0.0001^{*}$ \\
\hline Razmišljanje $\bullet$ Rumination & & 0.552 & $0.002^{*}$ \\
\hline Preuveličavanje $\bullet$ Magnification & & 0.524 & $0.003^{*}$ \\
\hline Bespomoćnost $\bullet$ Helplessness & & 0.787 & $0.0008^{*}$ \\
\hline
\end{tabular}

\section{Rasprava}

Budući da je SPU kronično bolno stanje za koje još nema odgovarajuće terapije, može se pretpostaviti da ga uzrokuje povećanje negativnih emotivnih stanja kao što su depresija, anksioznost i katastrofiziranje $(3,14)$. Ljestvica Pain Catastofizing ima maksimalnu vrijednost 52 koja se dobiva zbrajanjem iznosa koji su ispitanici upisali kao odgovore na postavljena pitanja (15). Prema autoru ljestvice, vrijednost od 40 ili veća upućuje na klinički značajno katastrofiziranje koje zahtijeva psihološku intervenciju. Od ukupno 30 ispitanika u ovoj studiji, njih devet (30\%) imalo je ukupni iznos katastrofiziranja 40 i više, što upućuje na veliki psihološki utjecaj koji SPU ima na gotovo trećinu bolesnika. Matsuoka i suradnici (3) navode katastrofiziranje kao jedan od glavnih disfunkcijskih spoznajnih čimbenika kod japanskih pacijenata sa SPU-om. Prosječno katastrofiziranje u našoj studiji iznosilo je 28,4 \pm 15 , što je slično rezultatima kod japanskih pacijenata $(28,19 \pm 9,70)(3)$. Najizraženija komponenta bila je razmišljanje čiji je bio prosječni iznos 10,2 \pm 5 od ukupno 16, odnosno 63,8 posto maksimalnog iznosa. Preuveličavanje i bespomoćnost bili su nešto slabije izraženi - iznosili su 57,5 posto $(6,9 \pm 3,4$; maks. 12$)$, odnosno 46,7 posto $(11,2$ \pm 7 ,4; maks. 24) maksimalnog iznosa. Da je u ovoj populaciji razmišljanje o vlastitu stanju dosta izraženo, svjedoči i činjenica da su pitanja koja su dobila najvišu ocjenu u OHIPovu upitniku bila: Jeste li razmišljali o svojim zubima, ustima,

\section{Discussion}

BMS is a chronic painful condition for which there is still no adequate treatment (13). Therefore, it is not surprising that BMS can cause an increase in negative emotional states such as depression, anxiety and catastrophizing and have negative impact on the quality of life $(3,14)$.

Pain Catastophizing Scale has a maximum score of 52, which is obtained by summing the values associated with the reply to each of the 13 statements (15). According to the authors, score above 40 presents clinically significant catastrophizing that requires psychological intervention. Out of the 30 patients in this study, 9 of them $(30 \%)$ had a total score above 40 , indicating a significant psychological impact that BMS has on almost one third of the patients. According to Matsuoka et al. (3) catastrophizing is a major dysfunctional cognitive factor in Japanese patients with BMS. Average catastrophizing score in this study was $28.4 \pm 15$ which is similar to the catastrophizing score in Japanese patients with BMS which was $28.19 \pm 9.70$ (3). Rumination was the most emphasized subcomponent of catastrophizing amounting to $10.2 \pm 5$ out of maximum 16 points $(63.8 \%)$. Magnification and helplessness were somewhat less emphasized, amounting to $6.9 \pm 3.4$ out of maximum 12 points $(57.5 \%)$ and 11.2 \pm 7.4 out of maximum 24 points $(46.7 \%)$. The fact that rumination is very strong in this population is further supported by the finding that the questions which obtained high- 
čeljustima ili protetskim radovima? i Jeste li bili i napeti zbog problema u ustima? Ovaj nalaz ne iznenađuje jer su simptomi umjerenog SPU-a $(5,8 \pm 2)$ prisutni cijeli dan, a prosječno trajanje tegoba iznosilo je 22 mjeseca. U razmjerno dugom razdoblju konstantno prisutnog bolnog poremećaja može se očekivati da će pacijenti manje ili više intenzivno razmišljati što im se događa te će nedobivanje odgovarajućeg objašnjenja pridonijeti generiranju frustracije i ostalih negativnih emocija. Utvrđena je značajna korelacija svih triju komponenti i ukupnog katastrofiziranja s intenzitetom simptoma. $S$ druge strane, nije ustanovljena značajna korelacija između trajanja simptoma i katastrofiziranja, što govori u prilog tome da bolesnici mogu dugo podnositi slabiju kroničnu bol. Ukupno katastrofiziranje i sve tri komponente pozitivno su korelirale s rezultatima iz upitnika OHIP-14. Ovaj nalaz potvrđuje snažnu vezu između katastrofiziranja i kvalitete života bolesnika s dijagnozom SPU-a. Katastrofiziranje je negativno utjecalo i na kvalitetu života ispitanika, što ne iznenađuje: pacijenti koji neprestano negativno razmišljaju o svojem stanju i osjećaju se bespomoćno imat će lošiju kvalitetu života u usporedbi s pacijentima koji, unatoč kroničnoj boli, pokušavaju normalno živjeti. Sličan je nalaz bio i za japansku populaciju sa SPU-om, ali i u slučaju drugih kroničnih bolnih stanja poput fibromijalgije, reumatoidnog artritisa, osteoartritisa i postherpetične neuralgije $(16-18)$. Još nije jasno je li katastrofiziranje uzrok ili posljedica kronične boli. Novije studije upućuju na to da je povezano s poremećenom regulacijom endogenih opioida za kontrolu boli (19).

Zašto je katastrofiziranje važno pacijentima sa SPU-om? Nekoliko je razloga zašto je potrebno imati uvid u pacijentovo katastrofiziranje. Kao što je već navedeno, katastrofiziranje utječe na pacijentov doživljaj boli te na način na koji je podnose $(8,19)$. Nadalje, katastrofiziranje je bolji prediktor odgovora na terapiju od čimbenika kao što su intenzitet boli, potrošnja lijekova, znanje o bolnom stanju, depresija, anksioznost i sl. $(7,16)$.

Mjerenje katastrofiziranja moglo bi pomoći u identifikaciji pacijenata $s$ negativnim obrascima ponašanja kod kojih bi se dodatnom psihološkom intervencijom (osim osnovne informacije o stanju koju daje specijalist oralne medicine) moglo smanjiti ili eliminirati negativne kognitivne čimbenike i poboljšati način podnošenja kroničnoga bolnog stanja kao što je SPU.

\section{Sukob interesa}

Nema sukoba interesa. est scores in OHIP-14, were related to the self-consciousness and psychological discomfort ("Have you been self-conscious because of your teeth or mouth?" and "Have you felt tense because of problems with your teeth or mouth?"). This is not surprising since symptoms in BMS were reported to be of moderate intensity (5.8 \pm 2$)$, present during the whole day with the average duration of 22 months. In a long period of more or less constant pain, it is expected that the patients will start ruminating about their condition generating frustration and other negative emotions.

All three subcomponents as well as total catastrophizing score significantly correlated with the intensity of the symptoms. On the other hand, no significant correlation was found between the duration of the symptoms and catastrophizing score, indicating that patients can cope with chronic pain for a long time provided the intensity is low.

Total catastrophizing score as well as all three subcomponents positively correlated with OHIP-14 scores. This finding suggests strong association between catastrophizing and quality of life in BMS patients. This is not surprising: patients who express negative thoughts about their condition and feel helpless are more likely to have lower quality of life than patients who try to maintain their normal daily functioning and cope with their condition. Similar results were reported in a Japanese BMS population as well as in other chronic pain conditions such as fibromyalgia, rheumatoid arthritis, osteoarthritis and postherpetic neuralgia (16-18). It is still unclear whether catastrophizing is a cause or consequence of chronic pain. Recent studies indicate that catastrophizing is associated with impaired regulation of endogenous pain-inhibitory opioids (19).

Why is catastrophizing important in BMS patients? It is necessary to have an insight into the patient's catastrophizing for several reasons. As stated earlier, catastrophizing affects the patient's experience of pain and the way patients cope with their pain $(8,19)$. Furthermore, catastrophizing is a better predictor of response to treatment than factors such as pain intensity, medication consumption, knowledge of the painful condition, depression, anxiety, etc. $(7,16)$.

In conclusion, measurement of catastrophizing in BMS patients may help in identifying individuals with negative behavioural patterns in whom additional psychological intervention (except for basic information about the condition provided by the oral medicine specialist) could reduce / eliminate negative cognitive factors and improve coping with chronic painful condition such as BMS.

\section{Conflict of interest}

No conflict of interest. 


\section{Abstract}

Background: Burning mouth syndrome (BMS) is an idiopathic painful condition which manifests with burning sensations in the oral cavity in patients with clinically normal oral mucosa and without any local and/or systemic causative factor. Catastrophizing is defined as an exaggerated negative orientation toward pain stimuli and pain experience. The aim of this study was to examine the association between catastrophizing and clinical parameters of BMS, and to examine the association between catastrophizing and the quality of life in patients with BMS. Materials and methods: Anonymous questionnaire consisting of 3 parts (demographic and clinical data with $100 \mathrm{~mm}$ visual analogue scale (VAS), Croatian version of the Oral Health Impact Profile (OHIP-14) scale and Croatian version of the Pain Catastrophizing scale (PC), was distributed to 30 patients diagnosed with BMS. Results: A higher level of catastrophizing was clinically significant in $30 \%$ of the patients. Total catastrophizing score and all three subcomponents of catastrophizing significantly correlated with the intensity of symptoms, but did not correlate with the duration of symptoms. Gender and previous treatment did not affect the catastrophizing. Conclusion: Obtaining the information about catastrophizing could help a clinician to identify patients with negative behavioural patterns. Additional psychological intervention in these individuals could reduce/eliminate negative cognitive factors and improve coping with chronic painful condition such as BMS.
Received: March 3, 2014

Accepted: May 7, 2014

Address for correspondence

Vlaho Brailo, DMD, PhD

University of Zagreb

School of Dental Medicine

Department of Oral Medicine

Gundulićeva 5, 10000 Zagreb, Croatia

brailo@sfzg.hr

Key words

Burning Mouth Syndrome;

Catastrophization; Quality of Life;

Adaptation Psychological

\section{References}

1. Grushka M, Epstein JB, Gorsky M. Burning mouth syndrome. Am Fam Physician. 2002 Feb 15;65(4):615-20.

2. López-Jornet P, Camacho-Alonso F, Andujar-Mateos P, SánchezSiles M, Gómez-Garcia F. Burning mouth syndrome: An update. Med Oral Patol Oral Cir Bucal. 2010 Jul 1;15(4):e562-8.

3. Matsuoka H, Himachi M, Furukawa H, Kobayashi, Shoki H, Motoya $R$ et al. Cognitive profile of patients with burning mouth syndrome in Japanese population. Odontology. 2010 Jul;98(2):1604.

4. Scala A, Checchi L, Montevecchi M, Marini I, Giamberardino MA. Update on burning mouth syndrome: overview and patient management. Crit Rev Oral Biol Med. 2003;14:275-291.

5. de Souza FT, Teixeira AL, Amaral TM, dos Santos TP, Abreu MH, Silva TA et al. Psychiatric disorders in burning mouth syndrome. J Psychosom Res. 2012 Feb;72(2):142-6.

6. Börsbo B, Peolsson M, Gerdle B. Catastrophizing, depression and pain: Correlation with and influence on quality of life and health a study of chronic whiplash associated disorders. J Rahabil Med. 2008 Jul; 40(7):562-9.

7. Meyer K, Sprott H, Mannion AF. Cross-cultural adaptation, reliability, and validity of the German version of the Pain Catastrophizing Scale. Journal of psyhosomatic research. 2008 May;64(5):469-78.

8. Vervoort T, Goubert L, Eccleston C, Vandenhende M, Clayes O, Clarke J et al. Expressive dimenions of the pain catastrophizing: An observational study in adolescents with cronic back pain. Pain. 2009 Nov;146(1-2):170-6.

9. Sullivan MJL, Bishop SR, Pivik J. The Pain Catastrophizing scale: Development and Validation. Psyhological Assessment. 1995;7:524-532.

10. Wu-Wang CY, Patel M, Feng J, Milles M, Wang SL. Decreased levels of salivary prostaglandin E2 and epidermal growth factor in recurrent aphthous stomatitis. Arch Oral Biol. 1995 Dec;40(12):1093-8.
11. Petričević N, Čelebić A, Papić M, Rener Sitar K. The Croatian vesrsion of the Oral Health Impact Profile Questionnaire. Coll Antropol. 2009 Sep;33(3):841-7.

12. Kraljević S, Banožić A, Marić A, Ćosić A, Sapunar D, Puljak L. Parents' pain catastrophizing is related to pain catastrophizing of their adult children. Int J Behav Med. 2012 Mar;19(1):115-9.

13. de Moraes M, do Amaral Bezerra BA, da Rocha Neto PC, de Oliveira Soares AC, Pinto LP, de Lisboa Lopes Costa A. Randomized trials for the treatment of burning mouth syndrome: an evidence-based review of the literature. J Oral Pathol Med. 2012 Apr;41(4):281-7.

14. Ni Riordain R, Moloney E, O'Sullivan K, McCreary C. Burning mouth syndrome and oral health-related quality of life: is there a change over time? Oral Dis. 2010 Oct;16(7):643-7.

15. Hsieh AY, Tripp DA, Ji LJ, Sullivan MJL. Comparison of Catastrophizing, Pain Attitudes, and Cold-Pressor Pain Experience Between Chinese and European Canadian Young Adults. The Journal of Pain. 2010 Nov;11(11):1187-94.

16. Mankovsky T, Lynch M, Clark A, Sawynok J, Sullivan MJ. Pain catastrophizing predicts poor response to topical analgesics in patients with neuropathic pain. Pain Res Manag. 2012 JanFeb;17(1):10-4.

17. Haythornthwaite JA, Clark MR, Pappagallo M, Raja SN. Pain coping strategies play a role in the persistence of pain in post-herpetic neuralgia. Pain. 2003 Dec;106(3):453-60.

18. Edwards RR, Bingham CO $3^{\text {rd }}$, Bathon J, Haythornthwaite JA. Catastrophizing and pain in arthritis, fibromyalgia, and other rheumatic diseases. Arthritis Rheum. 2006 Apr 15;55(2):325-32.

19. Goodin BR, McGuire L, Allshouse M, Stapleton L, Haythornthwaite JA, Burns $\mathrm{N}$ et al. Associations between catastrophizing and endogenous pain-inhibitory processes: Sex differences. J Pain. 2009 Feb;10(2):180-90. 